\title{
Huge Mass of Cutaneous-type Adult T-cell Leukemia Which Responded to Interferon Gamma
}

\author{
Taku Oba $^{1}$, Ritsuro Suzuki ${ }^{2}$, Koichi Miyamura ${ }^{1}$ and Yoshihisa Kodera ${ }^{1}$
}

Key words: adult T-cell leukemia, cutaneous lymphoma, interferon

\section{(DOI: 10.2169/internalmedicine.46.6319)}

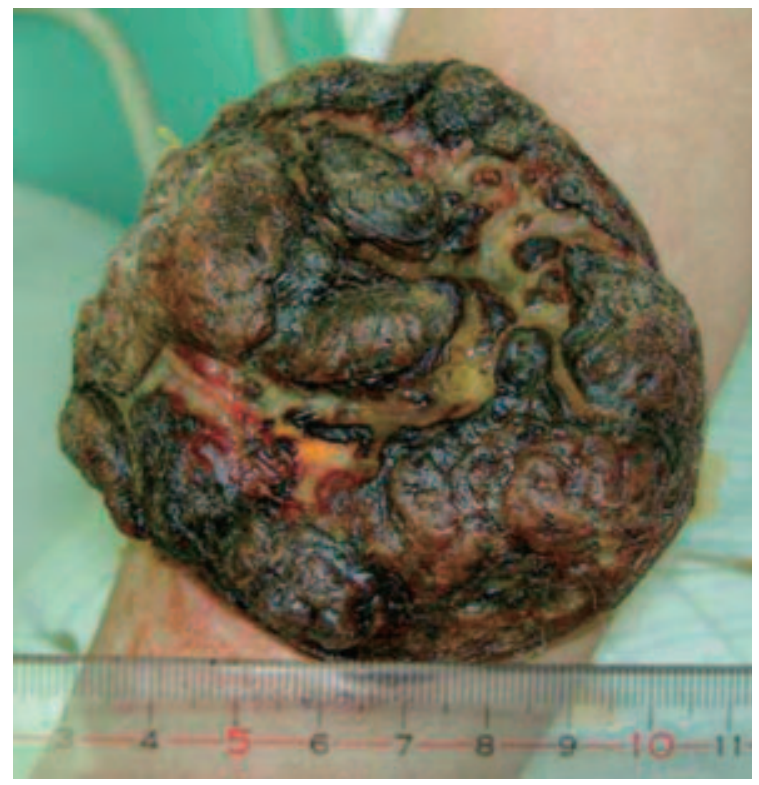

Figure 1. Cutaneous tumor developed on the upper right $\operatorname{arm}(7.5 \times 7 \times 5 \mathrm{~cm})$.

A 58-year-old Japanese woman presented with systemic macropapular eruption and fever. Skin biopsy showed a diffuse infiltration of pleomorphic large lymphocytes with $\mathrm{T}$ cell phenotype $\left(\mathrm{CD}^{+}, \mathrm{CD}^{+}, \mathrm{CD} 43^{+}\right.$and $\left.\mathrm{CD} 45 \mathrm{RO}^{+}\right)$. The diagnosis of cutaneous-type adult T-cell leukemia (ATL) was made because of the presence of serum anti-HTLV-I antibody and HTLV-I genome in the tumor cells. She received CHOP (cyclophosphamide, doxorubicin, vincristine and prednisone) chemotherapy with a very good partial response. Three years after onset, a huge mass with surface necrosis rapidly developed on her right upper limb (Fig. 1). Several

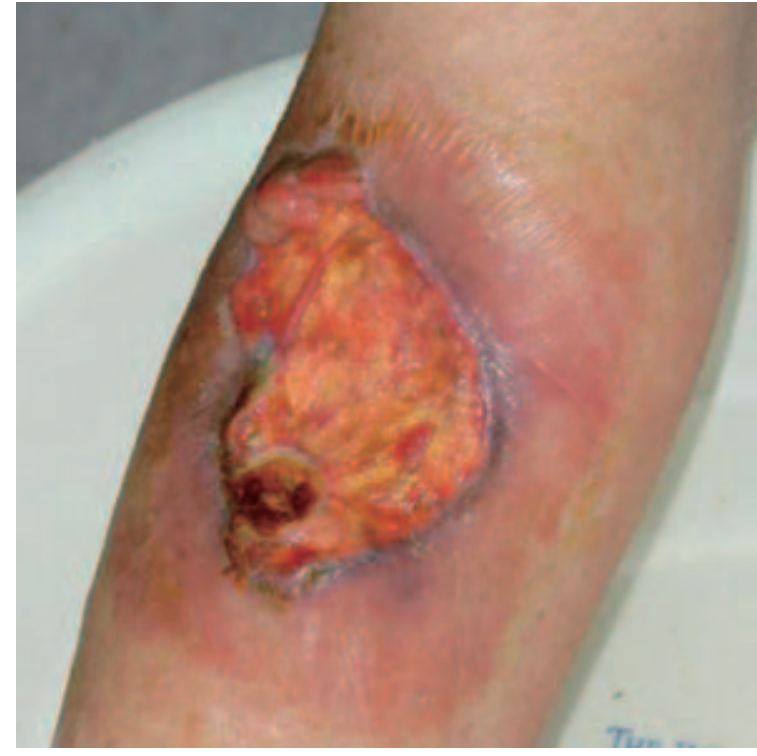

Figure 2. The tumor disappeared 50 days after initiation of interferon gamma monotherapy.

other small protuberating eruptions were scattered on her arms, but no other organ or lymph node involvement was found after systemic examinations. She was diagnosed with regrowth of cutaneous-type ATL, and interferon gamma-n1 (1 million units) was daily administered. The response was outstanding, and the tumor almost disappeared within 50 days (Fig. 2). Cutaneous-type ATL has been reported to require no aggressive treatment until progression occurs, although the prognosis is worse than previously thought. This case suggests that interferon gamma can be an option for this disease.

(C) 2007 The Japanese Society of Internal Medicine

http://www.naika.or.jp/imindex.html

\footnotetext{
${ }^{1}$ Department of Internal Medicine, Japanese Red Cross Nagoya First Hospital, Nagoya and ${ }^{2}$ Department of HSCT Data Management, Nagoya University School of Medicine, Nagoya

Received for publication October 18, 2006; Accepted for publication October 30, 2006

Correspondence to Dr. Ritsuro Suzuki,r-suzuki@mednagoya-u.ac.jp
} 